\title{
Sistematik Filogenetik Pseudomonas Strain Indigenous Pendegradasi Liniar Alkilbenzen Sulfonat
}

\author{
Phyllogenetic Systematic of Indigenous Strain of Pseudomonas Linear Alkylbenzene \\ Sulphonate-Degrading \\ Suharjono $^{1^{*}}$, Langkah Sembiring ${ }^{2}$, Yusup Subagja ${ }^{2}$, dan Wiwik E. Widayati ${ }^{3}$ \\ ${ }^{1}$ Jurusan Biologi FMIPA Universitas Brawijaya, Malang \\ ${ }^{2}$ Fakultas Biologi Universitas Gadjah Mada, Yogyakarta \\ ${ }^{3}$ Pusat Penelitian Perkebunan Gula Indonesia (P3GI), Pasuruan \\ E-mail: calistus@brawijaya.ac.id *Penulis untuk korespondensi
}

\begin{abstract}
Linear Alkylbenzene Sulphonate (LAS) was the dominant pollutant in the river ecosystem. Indigenous strains of Pseudomonas in river ecosystem had highly potency to LAS degradation. This research was carried out to study relationship of indigenous strains of LAS degrading to Pseudomonas strains. Indigenous strains of bacteria of LAS degrading were characterized based on ARDRA (Amplified Ribosomal 16S rDNA Restriction Analysis) and 16S rDNA sequence. Result of the research shows that Pseudomonas strain $J$ and $R$ which LAS degrading from detergent polluted river ecosystem based on 16S rDNA sequence, isolate $\mathrm{J}$ has $98.37 \%$ similarity and it has relationship to $P$. pseudoalcaligenes LMG $1225^{\mathrm{T}}$ whereas isolate $R$ has $84.86 \%$ similarity and related to $P$. stutzeri phen8.
\end{abstract}

Key words: Phyllogenetic, relationship, LAS, Pseudomonas

\begin{abstract}
Abstrak
Liniar Alkilbenzen Sulfonat (LAS) merupakan pencemar utama di ekosistem sungai. Strainstrain indigenous anggota Genus Pseudomonas di ekosistem sungai diketahui memiliki potensi tinggi dalam mendegradasi LAS. Penelitian ini bertujuan mempelajari kekerabatan strainstrain indigenous pendegradasi LAS terhadap strain-strain anggota Genus Pseudomonas. Strain-strain bakteri indigenous pendegradasi LAS dikarakterisasi berdasarkan ARDRA (Amplified Ribosomal 16S rDNA Restriction Analysis) dan sekuen 16S rDNA. Hasil penelitian menunjukkan bahwa Pseudomonas strain $\mathbf{J}$ dan $\mathbf{R}$ dari ekosistem sungai tercemar deterjen pendegradasi LAS berdasarkan ARDRA dan sekuen 16S rDNA, isolat $J$ memiliki nilai similaritas sekuen 16S rDNA 98,37\% dan secara filogenetik berkerabat dekat dengan $P$. pseudoalcaligenes LMG $1225^{\mathrm{T}}$ sedangkan isolat $\mathrm{R}$ berkerabat dengan $P$. stutzeri phen8 dengan nilai similaritas $84,86 \%$.
\end{abstract}

Kata kunci: Filogenetik, kekerabatan, LAS, Pseudomonas

Diterima: 23 Februari 2009, disetujui: 23 November 2009

\section{Pendahuluan}

Deterjen sintetik sebagai agen pembersih mengandung surfaktan anionik Liniar Alkilbenzen Sulfonat (LAS) (Campos-Garcia et al., 1999; Jerabkova et al., 1999; Huang et al., 2000; Schleheck et al., 2000). Surfaktan tersebut selalu ada dalam limbah permukiman dan terakumulasi di air dan sedimen ekosistem sungai (Jerabkova et al., 1999; Kenzaka et al., 2001). Hasil penelitian menunjukkan bahwa kandungan deterjen di dalam air Sungai Brantas sudah melampaui nilai ambang 0,5 $\mathrm{mg} / \mathrm{L}$ (Retnaningdyah et al., 1999; Mitakda et al., 2000; Suharjono, 2008).

Strain-strain bakteri anggota Genus Pseudomonas predominan di ekosistem sungai yang tercemar deterjen (Suharjono, 2008). Beberapa strain anggota genus tersebut berperan penting dalam biodegradasi dan mereduksi toksisitas limbah deterjen (Campos-Garcia et al., 1999; Jerabkova et al., 1999; Schleheck et al., 
2000 dan 2003; Suharjono et al., 2007a). Strainstrain bakteri memiliki plasmid Octana (OCT) penyandi enzim pendegradasi rantai alkil (Van Beilen et al., 2001; Smits et al., 2002; Dinamarca et al., 2003), plasmid Toluen (TOL) penyandi enzim pengatalisis pemecahan cincin benzene (McCoy, 2000; Wackett, 2003), dan operon $s s u$ (sulfonatesulfurutilization) $E A D C B F$ penyandi enzim untuk desulfonasi LAS (Kahnert et al., 2000; Schleheck et al., 2003).

Strain-strain bakteri Indigenous

pendegradasi LAS berdasarkan sifat fenotip dan sidik jari protein termasuk anggota Genus Pseudomonas (Suharjono et al., 2007b; Suharjono, 2008). Analisis sekuen 16S rDNA dengan ARDRA (Amplified Ribosomal DNA Restriction Analysis) sudah banyak digunakan untuk klasifikasi strain-strain bakteri anggota Genus Pseudomonas (Widmer et al., 1998; Cho dan Tiedje, 2000; Rangel-Castro et al., 2002; Scortichini et al., 2002; Di Battista - Leboeuf et al., 2003; Lagace et al., 2004). Menurut Spilker et al., (2004) amplifikasi gen 16S rDNA dengan $P C R$ yang diikuti $A R D R A$ dapat digunakan untuk mendeteksi dan diferensiasi strain-strain atau spesies anggota Genus Pseudomonas. Dalam penelitian ini digunakan enzim restriksi $R s a \mathrm{I}$ dan HinfI karena keduanya dapat menghasilkan fragmen-fragmen $16 \mathrm{~S}$ rDNA yang dapat membedakan beberapa kelompok strain bakteri.

Sekuen 16S rDNA sudah lama digunakan sebagai acuan dalam bidang taksonomi untuk klasifikasi dan penentuan filogeni spesiesspesies bakteri (Rangel-Castro et al., 2002). Dijelaskan pula bahwa identifikasi berdasarkan genotip tersebut untuk identifikasi spesies atau strain lebih akurat, andal, sederhana, objektif, serta memungkinkan pembedaan antarstrain atau spesies (Spilker et al., 2004). Menurut Di Battista-Leboeuf et al., (2003) metode tersebut untuk estimasi komposisi dan keanekaragaman anggota Genus Pseudomonas dalam habitat yang kompleks karena efektif untuk diskriminasi di antara spesies-spesies. Penelitian ini dilakukan untuk mengetahui kekerabatan strain-strain bakteri pendegradasi LAS indigenous ekosistem tercemar deterjen terhadap strain-strain anggota Genus Pseudomonas secara filogenetik berdasarkan similaritas sekuen 16S rDNA.

\section{Metode Penelitian}

Kromosom (DNA) isolat bakteri diisolasi dengan metode miniprep CTAB menurut Ausubel et al., (1997). Bahan genetik hasil isolasi disentrifugasi pada suhu $4^{\circ} \mathrm{C}, 3600 \mathrm{x} \mathrm{g}$, selama satu menit, kemudian gen 16S rDNA diamplifikasi dengan Thermocycler Gene Cycler (Biorad). Primer digunakan untuk amplifikasi gen 16S rDNA adalah P0(5'-GAG AGT TTG ATC CTG GCT CAG-3') dan P6(5'-CTA CGG CTA CCT TGT TAC GA-3') dari Roche. Primer tersebut universal untuk berbagai strain bakteri (Scortichini et al., 2002) dan dirancang Grifoni et al., (1995 cit. Scortichini et al., 2002) berdasarkan sekuen ujung 5' dan 3' gen 16S rRNA bakteri yang terkonservasi (posisi $27 \mathrm{f}$ dan 1495r pada 16S rDNA Escherichia coli) dan memungkinkan amplifikasi hampir keseluruhan gen.

Campuran untuk reaksi PCR terdiri atas $2 X$ PCR Master Mix (Fermentas) $10 \mu$ l, Primer P0 (27f) $1 \mu \mathrm{l}$, Primer P6 (1495r) $1 \mu \mathrm{l}$, DNA template $1 \mu \mathrm{l}$, dan akuabides bebas nuklease 7 $\mu$ l. Sampel disentrifugasi pada suhu $4^{\circ} \mathrm{C}, 9800 \mathrm{x}$ $\mathrm{g}$, selama 20 detik kemudian ditempatkan dalam Gen Cycler Biorad. Program amplifikasi 16S rDNA yaitu denaturasi awal $95^{\circ} \mathrm{C}$ selama dua menit, 35 siklus yang terdiri denaturasi pada $95^{\circ} \mathrm{C}$ selama 0,5 menit, annealing pada $55^{\circ} \mathrm{C}$ selama satu menit, dan ekstensi $72^{\circ} \mathrm{C}$ selama 1,5 menit; ekstensi akhir $72^{\circ} \mathrm{C}$ selama 10 menit, dan ekstensi akhir $37^{\circ} \mathrm{C}$ selama 5 menit. Amplikon gen $16 \mathrm{~S}$ rDNA dimurnikan dengan menggunakan Gel/PCR DNA Fragments Extraction Kit (Geneaid, Taiwan).

Amplikon 16S rDNA dianalisis dengan metode ARDRA menurut De Baere et al., (2002). Amplikon 16S rDNA sebanyak $15 \mu \mathrm{l}$ ditambahkan dua mikroliter buffer enzim restriksi, 2,5 $\mu$ l akuabides bebas nuklease, serta $0,5 \mu \mathrm{l}$ enzim restriksi $R s a \mathrm{I}$ atau HinfI (Roche) dengan konsentrasi $1 \mu \mathrm{g} / \mu \mathrm{l}$. Suspensi tersebut diinkubasikan selama 2,5 jam pada suhu $37^{\circ} \mathrm{C}$. Restriksi DNA dihentikan dengan penambahan lima mikroliter loading dye (blue juice) dan dipanaskan pada $65^{\circ} \mathrm{C}$ selama lima menit. Sampel dan DNA ladder 100 bp (N3231S dari Biolabs) kemudian dielektroforesis dengan menggunakan gel agarosa $2,0 \%(\mathrm{w} / \mathrm{v})$ pada 50 
volt selama 30 menit dalam $2 x$ buffer Tris-borat TBE yang mengandung $0,5 \mu \mathrm{g}$ ethidium bromida. Pola pita fragmen 16S rDNA pada gel agarosa dianalisis secara numerik dengan menggunakan program CLAD97 (Rahardi, 2002) untuk mengonstruksi dendrogram.

Amplikon 16S rDNA disekuensing dan dianalisis menurut metode Bhattacharya et al., (2003). Suspensi campuran pada reaksi PCR untuk sekuensing terdiri atas Bigdye V.3.1 sebanyak $4 \mu \mathrm{l}$, Buffer $4 \mu \mathrm{l}$, Primer $4 \mu \mathrm{l}$, dan DNA template $8 \mu \mathrm{l}$. Primer yang digunakan dalam reaksi PCR untuk sekuensing yaitu $\mathrm{P} 0$ (27f:5'-GAGAGTTTGATCCTGGCTCAG-3'), P4A (651f: 5'-AAT TAC TGG GCG TAA AG3'), P4 (651r: 5'-CTT TAC GCC CAG TAA TT3'), P3B (765r: 5'CTG TTT GCT CCC CAC GCT TTC-3'), P5 (930f: 5'-AAG GAA TTG ACG
GGG GC-3'), dan P6(1495r: 5'-CTA CGG CTA CCTTGT TAC GA-3'). Suspensi 16S rDNA hasil reaksi PCR sekuensing dipurifikasi dengan metode presipitasi etanol (Ausubel et al., 1997).

Amplikon 16S rDNA murni setiap strain disekuensing menggunakan ABI 3130 Genetic Analyzer. Sekuen DNA setiap strain dimasukkan ke program DNA Baser untuk menyambung dan mengoreksi setiap sekuen tersebut. Data sekuen 16S rDNA strain hasil isolasi dan strain acuan (Tabel 1) dilakukan alignment menggunakan program CLUSTALX. Pohon filogeni dikonstruksi dengan program PHYLIP (Phylogeny Inference Package) berdasarkan algoritma Neighbour-Joining dan matriks jarak evolusi menurut model Jukes dan Cantor (Saitou dan Nei, 1987 cit. Kim et al., 2000).

Tabel 1. Strain bakteri anggota Genus Pseudomonas untuk konstruksi pohon filogeni berdasarkan sekuen 16S rDNA.

\begin{tabular}{|c|c|c|c|}
\hline No & Acession Number & Nama Spesies & Kode Strain \\
\hline 1 & AF447394 & Pseudomonas putida & DLL-E4 \\
\hline 2 & AF284764 & Pseudomonas stutzeri & phen 8 \\
\hline 3 & AF321239 & Pseudomonas sp. & PM-2001 \\
\hline 4 & AF068259 & Pseudomonas jessenii & CIP $105274^{\mathrm{T}}$ \\
\hline 5 & AF058286 & Pseudomonas mandelii & CIP105273 \\
\hline 6 & $\mathrm{AB} 108691$ & Pseudomonas putida & AN2 \\
\hline 7 & AF064458 & Pseudomonas monteilii & CIP104883 \\
\hline 8 & AF072688 & Pseudomonas mosselii & CIP105259 \\
\hline 9 & AB029257 & Pseudomonas putida & IH-2000 \\
\hline 10 & AF094746 & Pseudomonas putida & ATCC17453 \\
\hline 11 & $\mathrm{AB} 126621$ & Pseudomonas japonica & IAM $15071^{\mathrm{T}}$ \\
\hline 12 & AF494092 & Burkholderia caryophylli & YS13 \\
\hline 13 & AB060137 & Pseudomonas cremoricolorata & IAM $1541^{\mathrm{T}}$ \\
\hline 14 & AB021397 & Pseudomonas asplenii & ATCC $23835^{\mathrm{T}}$ \\
\hline 15 & AY364537 & Pseudomonas lutea & $\mathrm{OK} 2^{\mathrm{T}}$ \\
\hline 16 & AB021381 & Pseudomonas fuscovaginae & MAFF301177 ${ }^{\mathrm{T}}$ \\
\hline 17 & AY11150 & Pseudomonas graminis & DSM11363 \\
\hline 18 & Z76666 & Pseudomonas pseudoalcaligenes & LMG1225 \\
\hline 19 & AB030583 & Pseudomonas alcaliphila & AL15-21 \\
\hline 20 & AF074383 & Pseudomonas migulae & CIP105470 \\
\hline 21 & AY512614 & Pseudomonas fluorescens & A1XB1-4 \\
\hline 22 & AF511433 & Pseudomonas fluorescens & $\mathrm{CCCO} 8$ \\
\hline 23 & AJ492828 & Pseudomonas congelans & DSM14939 ${ }^{\mathrm{T}}$ \\
\hline 24 & AJ492827 & Pseudomonas cannabina & CFBP2341 ${ }^{\mathrm{T}}$ \\
\hline 25 & AJ537603 & Pseudomonas proteolytica & CMS64 ${ }^{\mathrm{T}}$ \\
\hline 26 & $\mathrm{Z} 76665$ & Pseudomonas oleovorans & $\mathrm{DSM} 1045^{\mathrm{T}}$ \\
\hline 27 & D84006 & Pseudomonas alcaligenes & IAM12411 \\
\hline 28 & AF267911 & Pseudomonas synxantha & DSM13080 \\
\hline 29 & AY509898 & P. chlororaphis (P. aureofaciens) & DSM6698 \\
\hline 30 & AB021378 & Pseudomonas ficuserectae & $\mathrm{JCM} 2400^{\mathrm{T}}$ \\
\hline 31 & AJ492830 & Pseudomonas fulgida & DSM14938 ${ }^{\mathrm{T}}$ \\
\hline
\end{tabular}


Tabel 1. (lanjutan)

\begin{tabular}{|c|c|c|c|}
\hline No & Acession Number & Nama Spesies & Kode Strain \\
\hline 32 & AF268968 & Pseudomonas brenneri & CFML97-391 $^{\mathrm{T}}$ \\
\hline 33 & AF064461 & Pseudomonas cedrinalP. cedrella & CFML96-198 \\
\hline 34 & Z76660 & Pseudomonas coronafaciens & LMG13190 \\
\hline 35 & AF255337 & Pseudomonas reactans & LMG5329 \\
\hline 36 & AF374472 & Pseudomonas costantinii & CFBP5705 $^{\mathrm{T}}$ \\
\hline 37 & AB021398 & Pseudomonas cichorii & ATCC $10857^{\mathrm{T}}$ \\
\hline 38 & B021401 & Pseudomonas marginalis & ATCC $10844^{\mathrm{T}}$ \\
\hline 39 & $\mathrm{AB} 021373$ & Pseudomonas resinovorans & $\mathrm{ATCC} 14235^{\mathrm{T}}$ \\
\hline 40 & AY486367 & Pseudomonas aeruginosa & AU4594 \\
\hline 41 & AF302795 & Pseudomonas indica & IMT37 \\
\hline 42 & D84009 & Pseudomonas azotoformans & IAM1603 \\
\hline 43 & S230263 & Pseudomonas sp. & $\mathbf{J}$ \\
\hline 44 & $\mathrm{C} 230263$ & Pseudomonas sp. & $\mathrm{R}$ \\
\hline
\end{tabular}

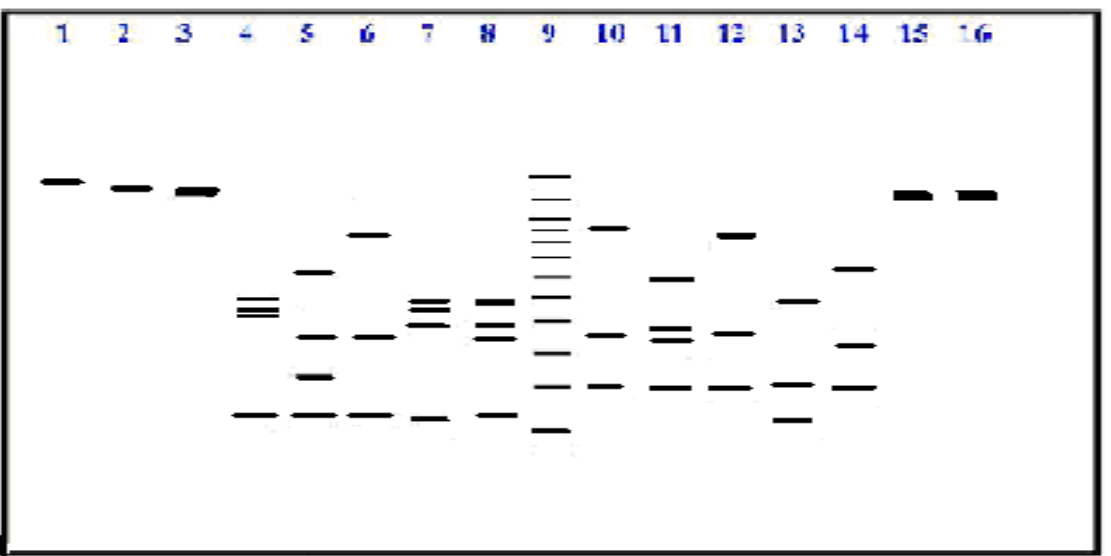

Gambar 1. Diagram representatif profil fragmen $16 \mathrm{~S}$ rDNA strain-strain bakteri hasil ristriksi dengan enzim RsaI dan HinfI.

Keterangan: 1, 2, 3, 15, dan 16 yaitu 16S rDNA utuh hasil PCR untuk strain R, J, $P$. aeruginosa, $P$. fluorescens, dan $P$. putida. No. $4-8$ adalah hasil restriksi $16 \mathrm{~S}$ rDNA dengan $R s a I$ untuk strain $\mathrm{R}, \mathrm{J}, P$. aeruginosa, $P$. fluorescens, dan $P$. putida. No. 10-14 adalah hasil restriksi $16 \mathrm{~S}$ rDNA dengan HinfI untuk strain R, J, P. aeruginosa, $P$. fluorescens, dan P. putida. No. 9 sebagai MarkerDNA ladder 100bp.

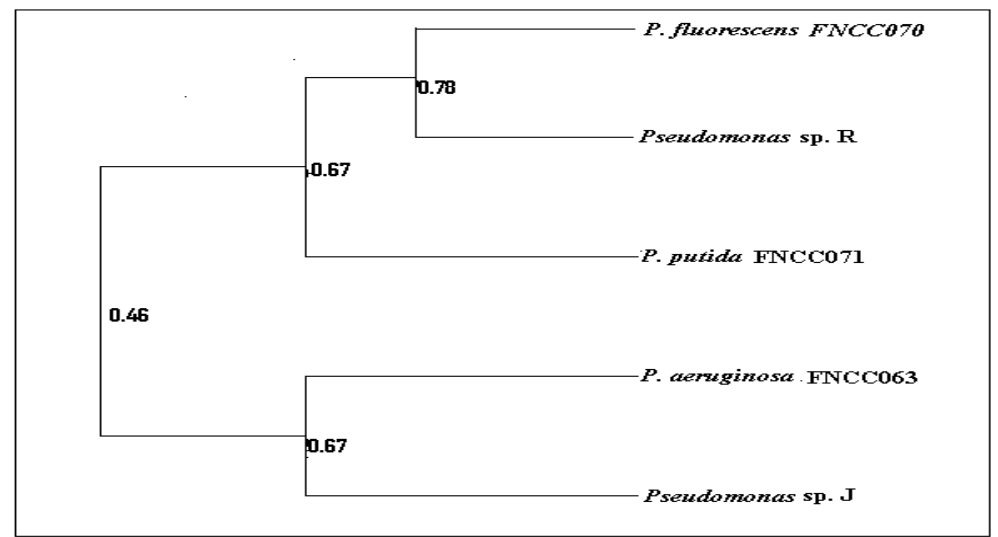

Gambar 2. Dendogram yang menunjukkan hubungan antara lima strain anggota Genus Pseudomonas didasarkan atas analisis $\mathrm{SS}_{\mathrm{M}}$ dan algoritma UPGMA terhadap profil fragmen $16 \mathrm{~S}$ rDNA hasil ristriksi enzim $R s a 1$. 


\section{Hasil dan Pembahasan}

Sekuen 16S rDNA tiap-tiap strain bakteri yang dipotong dengan enzim restriksi $R s a \mathrm{I}$ atau HinfI disajikan dalam bentuk diagram representatif (Gambar 1). Hasil analisis secara numerik sekuen 16S rDNA yang dipotong dengan enzim restriksi RsaI (Gambar 2) menunjukkan Pseudomonas sp. $\mathrm{R}$ memiliki nilai similaritas paling tinggi sebesar 0,78 dengan $P$. fluorescens FNCC070, keduanya mempunyai fragmen 16S rDNA dengan jumlah pasangan basa 140, 420, dan $460 \mathrm{bp}$; tetapi tidak memiliki fragmen 220, 330, 590, dan $900 \mathrm{bp}$. Pseudomonas sp. $\mathrm{R}$ berbeda dengan $P$. fluorescens FNCC070 karena memiliki fragmen 16S rDNA 390 bp tetapi tidak memiliki 380 bp. Pseudomonas sp. $\mathrm{J}$ paling tinggi nilai similaritasnya sebesar 0,67 dengan $P$. aeruginosa FNCC063, keduanya memiliki fragmen 16S rDNA 140 dan 330 bp serta tidak memiliki fragmen-fragmen 380, 390, 420, dan $460 \mathrm{bp}$. Fragmen 16S rDNA yang membedakan kedua strain tersebut yaitu Pseudomonas sp. J memiliki fragmen 220 dan 590 bp tetapi tidak memiliki fragmen $900 \mathrm{bp}$, sedangkan $P$. aeruginosa FNCC063 memiliki ciri sebaliknya.

Hasil analisis secara numerik sekuen 16S rDNA yang dipotong dengan enzim restriksi Hinfl (Gambar 3) menunjukkan Pseudomonas sp. R juga memiliki nilai similaritas paling tinggi sebesar 0,88 dengan P. fluorescens FNCC070, keduanya memiliki fragmen 190, 340, dan 600 bp tetapi tidak memiliki fragmen 130, 460, 820, dan 970 bp. P. fluorescens FNCC070 memiliki fragmen 16S rDNA 300 bp tetapi Pseudomonas sp. R tidak memilikinya. Pseudomonas sp. J memiliki nilai similaritas terendah 0,47 terhadap strain bakteri lainnya.

Dalam penelitian ini digunakan enzim restriksi RsaI dan HinfI karena keduanya dapat menghasilkan fragmen-fragmen $16 \mathrm{~S}$ rDNA yang dapat membedakan beberapa kelompok strain bakteri, sedangkan enzim AluI dan MspI hanya menghasilkan satu kelompok strain. Hasil ARDRA dengan enzim RsaI dan Hinfl dalam penelitian ini menghasilkan pola fragmen $16 \mathrm{~S}$ rDNA yang berbeda. Klasifikasi berdasarkan ARDRA ini memiliki korelasi positif dengan klasifikasi berdasarkan sidik jari protein, dan hasilnya lebih baik dan objektif dibandingkan dengan sistem klasifikasi fenotipik. Berdasarkan ketiga sistem klasifikasi tersebut menunjukkan bahwa kedua strain hasil isolasi merupakan spesies yang berbeda dari anggota Genus Pseudomonas. Menurut Spilker et al., (2004) amplifikasi gen $16 \mathrm{~S}$ rDNA dengan $P C R$ yang diikuti dengan ARDRA/RFLP dapat untuk mendeteksi dan diferensiasi strain atau spesies anggota Genus Pseudomonas.

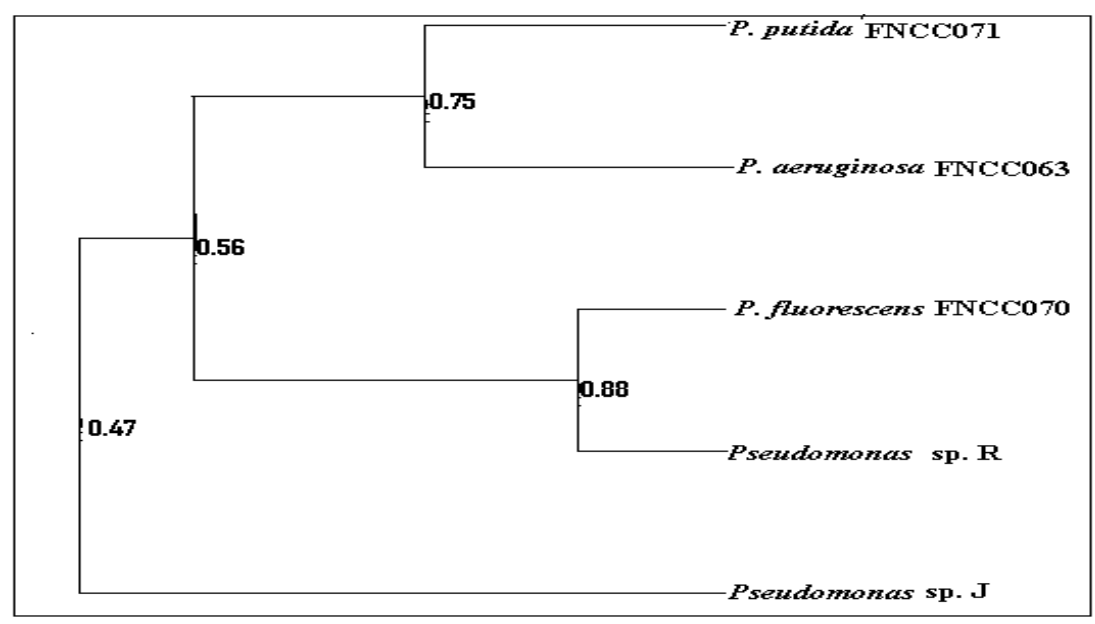

Gambar 3. Dendogram yang menunjukkan hubungan antara lima strain anggota Genus Pseudomonas didasarkan atas analisis $\mathrm{SS}_{\mathrm{M}}$ dan algoritma UPGMA terhadap profil fragmen 16S rDNA hasil ristriksi enzim Hinfl. 
Berdasarkan ARDRA tersebut menunjukkan bahwa kedua strain hasil isolasi merupakan spesies yang berbeda dari anggota Genus Pseudomonas. Oleh karena itu dilakukan analisis berdasarkan pohon filogeni dari sekuen 16S rDNA. Sekuen 16S rDNA Pseudomonas sp. J memiliki panjang 1432 bp sedangkan untuk Pseudomonas sp. $\mathrm{R}$ panjangnya $1455 \mathrm{bp}$. Berdasarkan pohon filogeni (Gambar 4) dan similaritas sekuen 16S rDNA (Tabel 2) menunjukkan bahwa Pseudomonas sp. J memiliki hubungan kekerabatan yang paling erat dengan kelompok bakteri $P$. oleovorans DSM $1045^{\mathrm{T}}$ dan $P$. pseudoalcaligenes LMG $1225^{\mathrm{T}}$, sedangkan Pseudomonas sp. R paling erat kekerabatannya dengan $P$. stutzeri phen 8 . Strain bakteri Pseudomonas sp. J memiliki nilai similaritas sekuen 16S rDNA sebesar 97,62\% terhadap $P$. oleovorans DSM1045 ${ }^{\mathrm{T}}$, yaitu sebanyak 32 nukleotida yang berbeda dari 1346 nukleotida yang dibandingkan. Pseudomonas sp. $\mathrm{J}$ tersebut memiliki nilai similaritas sekuen $16 \mathrm{~S}$ rDNA sebesar $98,37 \%$ terhadap $P$. pseudoalcaligenes $\mathrm{LMG}^{2} 25^{\mathrm{T}}$, yaitu ada 22 nukleotida yang berbeda dari 1349 nukleotida. Nilai similaritas sekuen 16S rDNA antara Pseudomonas sp. $\mathrm{R}$ dengan $P$. stutzeri phen8 sebesar 84,86\%, yaitu ada 211 nukleotida yang berbeda dari 1394 nukleotida.

Menurut konsep spesies untuk bakteri berdasarkan nilai similaritas sekuen 16S rDNA dinyatakan bahwa spesies merupakan kumpulan strain-strain yang memiliki nilai similaritas lebih dari 97\% (Stackebrandt, 1994 cit. Dijkshoorn et al., 2000; Bossis et al., 2000). Berdasarkan konsep tersebut Pseudomonas sp. J merupakan anggota $P$. oleovorans atau $P$. pseudoalcaligenes, tetapi berdasarkan nilai similaritasnya Pseudomonas sp. J lebih mirip dengan $P$. pseudoalcaligenes LMG1225 daripada dengan $P$. oleovorans DSM1045 ${ }^{\mathrm{T}}$. Bila dilihat bahwa $P$. oleovorans DSM1045 ${ }^{\mathrm{T}}$ dan $P$. pseudoalcaligenes $\mathrm{LMG}^{2} 25^{\mathrm{T}}$ yang hanya memiliki 11 nukleotida yang berbeda merupakan spesies yang berbeda, berarti kedua isolat hasil isolasi merupakan spesies yang berbeda dari kedua spesies anggota Genus Pseudomonas tersebut. Menurut Bossis et al., (2000) dan Cladera et al., (2004) bila dua strain atau lebih memiliki nilai similaritas sekuen $16 \mathrm{~S}$ rDNA lebih dari $97 \%$, untuk menentukan strain-strain tersebut sebagai strain yang sama atau berbeda harus dilakukan analisis hibrisasi DNA. Suatu strain berdasarkan hibridisasi DNA memiliki similaritas sekuen lebih dari $99 \%$ dan perbedaan suhu denaturasi DNA kurang dari lima derajat celcius.

Hasil analisis sekuen 16S rDNA tersebut menunjukkan Pseudomonas sp. J, Pseudomonas sp. $\quad \mathrm{R}, \quad P$. stutzeri, $P$. Alcaligenes, $P$. pseudoalcaligenes, $P$. oleovorans, dan $P$. resinovorans berada dalam satu grup dengan $P$. aeruginosa. Hasil ini sesuai dengan klastering berdasarkan sekuen 16S rRNA yang dilakukan oleh Anzai et al., (2000) dan Yamamoto et al., (2000). Strain-strain bakteri yang diuji termasuk anggota Pseudomonas grup I berdasarkan homologi sekuen RNA yaitu Genus Pseudomonas yang sebenarnya menurut Krieg dan Holt (1984).

Hasil identifikasi kedua bakteri yaitu Pseudomonas sp. J dan Pseudomonas sp. R berdasarkan ARDRA ternyata kurang akurat dibandingkan dengan berdasarkan sekuen 16S rDNA. Untuk identifikasi bakteri berdasarkan ARDRA diperlukan banyak strain acuan dalam genus yang sama dan hanya menunjukkan nilai similaritasnya. Oleh karena itu identifikasi kedua bakteri tersebut lebih valid hasilnya berdasarkan sekuen 16S rDNA yang dapat menunjukkan hubungan kekerabatan dan similaritasnya. Namun, diperlukan data sekuen 16S rDNA dari seluruh strain anggota genus tersebut untuk memastikan nama strain atau spesies isolat bakteri tersebut. Selain itu hasilnya perlu diverifikasi dengan sistem klasifikasi berdasarkan hibridisasi DNA dan sistem klasifikasi yang lain. Hal ini disebabkan sistem klasifikasi yang hanya berdasarkan satu jenis karakter saja tidak dapat digunakan untuk memasukkan atau memisahkan suatu strain ke dalam atau dari suatu spesies bakteri. 


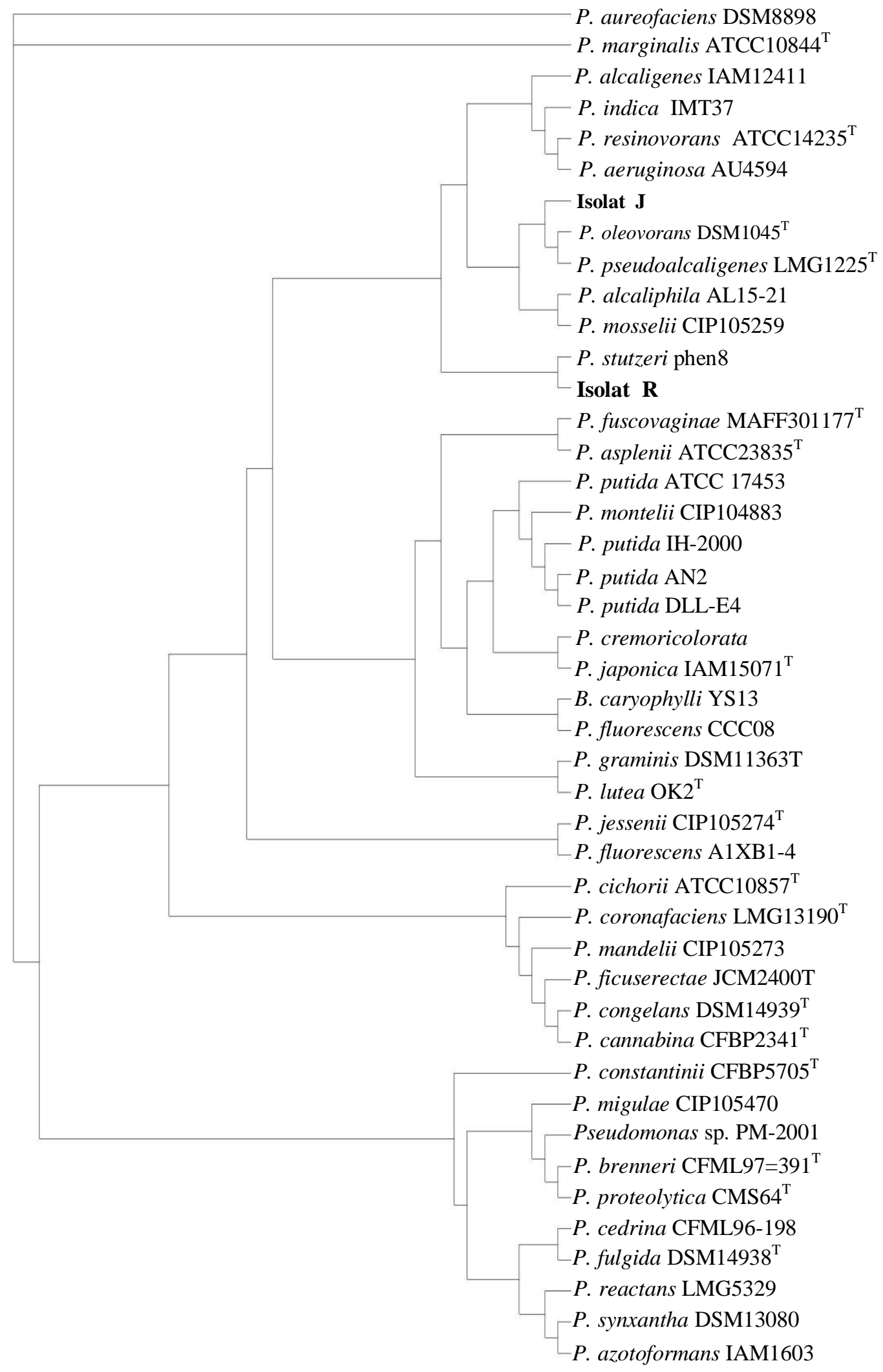

Gambar 4. Pohon filogeni yang dibuat berdasarkan algoritma Neighbour-joining (Saitou dan Nei, 1987) yang menunjukkan hubungan antara strain acuan dan isolat bakteri pendegradasi LAS atas dasar sekuen 16S rDNA. 
Tabel 2. Nilai similaritas $16 \mathrm{~S}$ rDNA (\%) dan jumlah nukleotida yang berbeda antara strain acuan dan isolat bakteri pendegradasi LAS dalam klaster $P$. Aeruginosa.

\begin{tabular}{|c|c|c|c|c|c|c|c|c|c|c|c|}
\hline Strain & $\begin{array}{c}D \\
84006 \\
\end{array}$ & $\begin{array}{c}\mathbf{A F} \\
\mathbf{3 0 2 7 9 5} \\
\end{array}$ & $\begin{array}{c}\text { AB } \\
021398 \\
\end{array}$ & $\begin{array}{c}\text { AY } \\
\mathbf{4 8 6 3 6 7} \\
\end{array}$ & $\begin{array}{c}S \\
230263 \\
\end{array}$ & $\begin{array}{c}Z \\
76665 \\
\end{array}$ & $\begin{array}{c}Z \\
76666 \\
\end{array}$ & $\begin{array}{c}\mathrm{AB} \\
\mathbf{0 3 0 5 8 3} \\
\end{array}$ & $\begin{array}{c}\mathbf{A F} \\
072688 \\
\end{array}$ & $\begin{array}{c}\text { AF } \\
284764 \\
\end{array}$ & $\begin{array}{c}\mathrm{C} \\
230263 \\
\end{array}$ \\
\hline 6 & -- & $/ 1142$ & 39 & 1370 & 1364 & 425 & $/ 1429$ & 1426 & 63 & 133 & $7 /$ \\
\hline AF 302795 & 95,63 & --- & $63 / 1438$ & 47/1371 & $68 / 1347$ & $74 / 1426$ & $64 / 1430$ & $69 / 1427$ & $9 / 1360$ & $72 / 1418$ & $227 / 1393$ \\
\hline AB 021398 & 95,41 & 95,62 & --- & $74 / 1369$ & $65 / 1348$ & $62 / 1425$ & $52 / 1429$ & $51 / 1426$ & $694 / 1361$ & $64 / 1419$ & $216 / 1392$ \\
\hline AY 486367 & 97,15 & 96,57 & 94,59 & -- & $46 / 1330$ & $51 / 1368$ & $41 / 1372$ & $46 / 1372$ & $676 / 1322$ & $42 / 1373$ & $200 / 1360$ \\
\hline S 230263 & 96,48 & 94,95 & 95,18 & 96,54 & 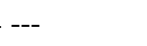 & $32 / 1346$ & $22 / 1349$ & $27 / 1349$ & $667 / 1303$ & $48 / 1368$ & $204 / 1340$ \\
\hline Z 76665 & 96,84 & 94,81 & 95,65 & 96,27 & 97,62 & --- & $11 / 1428$ & $15 / 1425$ & $690 / 1357$ & $42 / 1416$ & $217 / 1391$ \\
\hline Z 76666 & 97,55 & 95,52 & 96,36 & 97,01 & 98,37 & 99,23 & --- & $6 / 1429$ & $693 / 1361$ & $33 / 1420$ & $212 / 1395$ \\
\hline AB 030583 & 97,27 & 95,16 & 96,42 & 96,65 & 98,0 & 98,95 & 99,58 & --- & $691 / 1361$ & $36 / 1420$ & $212 / 1395$ \\
\hline AF 072688 & 48,94 & 48,6 & 49,0 & 48,87 & 48,8 & 49,2 & 49,1 & 49,2 & -- & $706 / 1366$ & $712 / 1342$ \\
\hline $\mathrm{AF} 2$ & 96,58 & 94,92 & 95,49 & 96,94 & 96,49 & 97,03 & 97,68 & 97,46 & 48,3 & --- & $211 / 1394$ \\
\hline C 230263 & 84,42 & 83,7 & 84,48 & 85,29 & 84,78 & 84,4 & 84,8 & 84,8 & 46,9 & 84,86 & -- \\
\hline
\end{tabular}

\section{Simpulan dan Saran}

\section{Simpulan}

Strain-strain indigenous pendegradasi LAS merupakan anggota Genus Pseudomonas endemik Indonesia. Pseudomonas sp. strain J berkerabat dekat dengan $P$. pseudoalcaligenes LMG $1225^{\mathrm{T}}$ dengan nilai similaritas sekuen $16 \mathrm{~S}$ rDNA sebesar 98,37\% sedangkan isolat $\mathrm{R}$ lebih berkerabat dekat dengan $P$. stutzeri phen8 dengan nilai similaritas $84,86 \%$.

\section{Saran}

Untuk memastikan nama spesies dan strain, maka sekuen 16S rDNA kedua isolat perlu diverivikasi similaritasnya dengan strainstrain anggota Spesies $P$. pseudoalcaligenes dan P. stutzeri.

\section{Ucapan Terima Kasih}

Penelitian ini dibiayai dari dana program TPSDP dan DPP/SPP. Oleh karena itu, ucapan terima kasih disampaikan kepada Direktur SPMU TPSDP dan Dekan FMIPA Universitas Brawijaya. Ucapan terima kasih juga disampaikan kepada Bapak Dr. Wahyu Purbowasito yang membantu dalam sekuensing 16S rDNA.

\section{Daftar Pustaka}

Anzai, Y., Kim, H., Park, J.Y., Wakabayashi, H. dan Oyaizu, H. 2000. Phylogenetic Affiliation of the Pseudomonads Based on 16S rRNA Sequence. IJSEM, 50: 1563-1589.
Ausubel, F.M., Brent, R., Kingston, R.E., Moore, D.D., Seidman, J.G., Smith, J.A. dan Struhl, K. 1997. Current Protocols in Molecular Biology. Vol. 1. John Wiley \& Sons, Inc., USA.

Bhattacharya, D., Sarma, P.M., Krishnan, S., Mishra, S. dan Lal, B. 2003. Evaluation of Genetic Diversity among Pseudomonas citronellolis Strains Isolated from Oily Sludge-Contaminated Sites. Appl. Environ. Microbiol, 69 (3): 1435-1441.

Bossis, E., Lemanceau, P., Latour, X. dan Gordon, L. 2000. The Taxonomy of Pseudomonas fluorescens and Pseudomonas putida: Current Status and Need for Revision. Agronomie, 20: 51-63.

Campos-Garcia, J., Esteve, A., Vasquez, R., Ramos, J.L. dan Soberon, C.G. 1999. The Branched-Chain Dodecylbenzene Sulfonate Degradation Pathway of Pseudomonas aeruginosa W51D Involves a Novel Route for Degradation of the Surfactant Lateral Alkyl Chain. Appl. Environ. Microbiol, 65 (8): 3730-3734.

Cho, J.C. dan Tiedje, J.M. 2000. Biogeography and Degree of Endemicity of Fluorescent Pseudomonas Strains in Soil. Appl. Environt. Microbiol, 66 (12): 5448-5456.

Cladera, A.M., Bennasar, A., Borcelo, M., Lalucat, J. dan Garcia-Valdes, E. 2004. Comparative Genetic Diversity of Pseudomonas stutzeri Genomovars, Clonal Structure, and Phylogeny of the Species. J. Bacteriol, 186 (16): 5239-5248.

De Baere, T., De Mendonca, K., Claeys, G., Vershraegen, G., Mijs, W., Verhelst, R., Rottiers, S., Simaey, L.V., De Ganck, C. dan Vaneechaute, M. 2002. Evaluation of Amplified rDNA Restriction Analysis (ARDRA) for the Identification of Cultured Mycobacteria in a Diagnosis Laboratory. BioMed Central Microbiology, 2 (4): 1-12. 
Di Battista-Leboeuf, C., Benizri, E., Corbel, G., Piutti, S. dan Guckert, A. 2003. Distribution of Pseudomonas sp. Populations in Relation to Maize Root Location and Growth Stage. Agronomie, 23: 441-446.

Dinamarca, M.A., Aranda-Olmedo, I., Puyet, A. dan Rojo, F. 2003. Expression of the Pseudomonas putida OCT Plasmid Alkane Degradation Pathway is Modulated by Rwo Different Global Control Signals: Evidence from Continuous Cultures. J. Bacteriol, 185 (6): 4772-4778.

Huang, H., Ellis, T.G. dan Kaiser, S.K. 2000. Extant Biodegradation Testing with Linear Alkybenzene Sulfonate in Laboratory and Field Activated Sludge Systems. WEFTEC, Water Environmental Federation.

Jerabkova, H., Kralova, B. dan Nahlik, J. 1999. Biofilm of Pseudomonas $\mathrm{C} 12 \mathrm{~B}$ on Glass Support as Catalytic Agent for Continuous SDS Removal. Int. Biodet. Biodeg, 44: 233-241.

Kahnert, A., Vermeij, P., Wietek, C., James, P., Leisinger, T. dan Kartesz, M.A. 2000. The ssu locus Plays a Key role in Organosulfur Metabolism in Pseudomonas putida S-313. J. Bacteriol, 182 (10): 2869-2878.

Kenzaka, T., Yamaguci, N., Prapagde, B., Mikami, E. dan Nasu, M. 2001. Bacterial Community Composition and Activity in Urban Rivers in Thailand and Malaysia. J. Health Sci., 47 (4): 353-361.

Kim, S., Chun, J., Bae, K.J. dan Kim, Y. 2000. Polyphasic Assignment of an Aromatic-degrading Pseudomonas sp. Strain Dj.77 in the genus Spingomonas as Spingomonas chungbukensis sp., nov. Int. J. Syst. Evol. Microbiol, 50: 1641-1647.

Krieg, N.R. dan Holt, J.G. 1984. Bergey's Manual of Systematic Bacteriology. Vol. 1. William \& Wilkins, London.

Lagace, L., Pitre, M., Jacques, M. dan Roy, D. 2004. Identification of the Bacterial of the Maple Sap by Using Amplified Ribosomal DNA (rDNA) Restriction Analysis and rDNA Sequencing. Appl. Environt. Microbiol, 70 (4): 2052-2060.

McCoy, M.M. 2000. Determination of the Presence of the Catabolic Alkane Monooxygenase Gene from Soil Microorganisms Isolated from Coastal Sand Dunes. Biological Sciences Department, College of Science and Mathematics, California Polytechnic State University, San Luis Oispo.

Mitakda, B., Prayitno, Suharjono dan Retnaningdyah, C. 2000. Perancangan dan Pemodelan Usaha Peningkatan Kemampuan Purifikasi Sungai Brantas Hilir. Natural, 4 (2): 38-49.
Rahardi, B. 2002. Pemrograman Aplikasi Konstruksi Kekerabatan Taksonomi dengan Visual C++6.0. Skripsi. Jurusan Biologi FMIPA, Universitas Brawijaya, Malang.

Rangel-Castro, J.I., Leventers, J.J. dan Donell, E. 2002. Physiological and Genetic Characterization of Fluorescent Pseudomonas associated with Cantharellus cibarius. Can. J. Microbiol, 48: 739-748.

Retnaningdyah, C., Samino, S., Suharjono, I., Doddy dan Prayitno. 1999. Uji Toksisitas Akut Surfaktan Deterjen LAS dan ABS terhadap Beberapa Gastropoda Sungai. Natural, 3 (2): 63-74.

Schleheck, D., Wong, W., Denger, K., Heinzle, E. dan Cook, A.M. 2000. An $\alpha$-Proteobacterium Convetrs Linear Alkylbenzene Sulfonate Surfactants into Sulfophenyl Carboxylates and Linear Alkyldiphenylether disulfonate Surfactants into Sulfodiphenyl Ether Carboxylates. Appl. Environ. Microbiol, 66 (5): 1911-1916.

Schleheck, D., Lechner, M., Schonemberger, R., Suter, M.J.F. dan Cook, A.M. 2003. Desulfonation and Degradation of the Disulfodiphenylethercarboxylates from Linear Alkyldipheniletherdisulfonate Surfactant. Appl. Environ. Microbiol, 69 (2): 938-944.

Scortichini, M., Marchesi, U., Rossi, M.P. dan Di Prospero, P. 2002. Bacteria Associated with Hazelnut (Corylus avellana L.) Decline Are of Two Groups: Pseudomonas avellanae and Strains Resembling $P$. syringae pv. syringae. Appl. Environ. Microbiol, 68 (2): 476-484.

Smits, T.H.M., Balada, S.B., Witholt, B. dan Van Beilen, J.B. 2002. Functional Analysis Alkana Hydroxylases from Gram Nrgative and Gram Positive Bacteria. J. Bacteriol, 184 (6): 1733-1742.

Spilker, T., Coenye, T., Vandamme, P. dan Li Puma, J.J. 2004. PCR Base Assay for Differentiation of $P$. aeruginosa from other Pseudomonas Species Recovered from Cystic Fibrosis Patients. J. Clin. Microbiol, 42 (5): 2074-2079.

Suharjono. 2008. Keanekaragaman dan Potensi Pseudomonas Strain Indigenous Pendegradasi Surfaktan Anionik di Ekosistem Sungai Tercemar Deterjen. Disertasi. Fakultas Biologi, Universitas Gadjah Mada, Yogyakarta.

Suharjono, Subagja, J., Sembiring, L., Retnaningdyah, C. dan Putra, I.K.J.W. 2007a. Pengaruh Penambahan Nitrogen dan Fosfor terhadap Potensi Strain-Strain Anggota Pseudomonas dalam Mendegradasi Liniar Alkibenzen Sulfonat. Berkala Penelitian Hayati, 12 (2): 107-114. 
Suharjono, Sembiring, L., Subagja, J., Ardyati, T. dan Lisdiana, L. 2007b. Sistematik Numerik StrainStrain Anggota Genus Pseudomonas Pendegradasi Alkilbenzen Sulfonat Liniar Berdasarkan Sifat Fenoip dan Protein Fingerprinting. Biota, 12 (1): 47-54.

Van Beilen, J.B., Panke, S., Lucchini, S., Ranchini, A.G., Rothlisberger, M. dan Witholt, B. 2001. Analysis of Pseudomonas putida AlkaneDegradation Gene Clusters and Flanking Insertion Sequences: Evolution and Regulation of the alk Genes. Microbiology, 147: 1621-1630.

Wackett, L. 2003. Pseudomonas putida a Versatile Biocatalyst. Nat. Biotechnol., 21 (2): 136-138.
Widmer, F., Seidler, R.J., Gillavet, P.M., Watrud, L.S. dan DiGiovanni, G.D. 1998. A Highly Selective PCR Protocol for Detecting 16S rRNA Genes of the Genus Pseudomonas (sensu stricto) in Environmental Samples. Appl. Environ. Microbiol., 64 (7): 2545-2553.

Yamamoto, S., Kasai, H., Arnold, D.L., Jackson, R.W., Vivian, A. dan Harayama, S. 2000. Phylogeny of the Genus Pseudomonas: Intragenic Structure Reconstructed from the Nucleotide Sequences of $g y r B$ and $r p o D$ Genes. Microbiology, 146: 2385-2394. 